\title{
Electoral Defeat, Conversational Practices of Blame and Avoidance of Responsibility in Nigerian Media Political Discourses
}

\author{
E. C. Krisagbedo \\ Use of English Unit, School of General Studies, University of Nigeria, Nsukka, Nigeria \\ C. U. Agbedo \\ Department of Linguistics, Igbo \& Other Nigerian Languages, University of Nigeria, Nsukka, Nigeria
}

A. K. Abubakar

Department of Linguistics, Igbo \& Other Nigerian Languages, University of Nigeria, Nsukka, Nigeria

Y. Ibrahim

Department of English, Kogi State College of Education, Ankpa, Nigeria

\begin{abstract}
This paper addresses electoral defeat suffered by the Peoples' Democratic Party (PDP) at the 2015 presidential polls and the communicative character of blame and avoidance of responsibility as evident in the Nigerian media political discourses. Discourse analysts are yet to study the linguistic aspects of blame and avoidance of responsibility in great details. This work is intended as a contribution towards filling this lacuna in knowledge by examining the conversational discursive practices adopted by Nigerian politicians in the circumstances of blame risk to achieve the twin goals of positive self-presentation and consolidation of political capital (Hansson, 2015). Some PDP members enlisted the discursive strategies of blame avoidance, in which blames and denials are carefully and strategically planned to serve positive self-representation (semantic macro-strategy of in-group favouritism) and negative other-representation, that is, semantic macro-strategy of derogation of out-group, (https://www.hse.ru/en/). We illustrate the linguistic mechanism of blame and avoidance of responsibility and how it thrives as a dominant recurrent theme in conflict talk and public communication discourses. The findings tend to enrich and enliven the literature on discourse studies and by extension open fresh vistas of critical research into language use in politics.
\end{abstract}

Index Terms - adjacency pairs, argumentative moves, blame, discursive strategies, electoral defeat, felicity conditions, Nigeria

\section{INTRODUCTION}

Discourse - language use in speech and writing - is viewed from the theoretical prism of Critical Discourse Analysis (CDA) as a form of 'social practice,' (https://pt.scribd.com). Describing discourse as a social practice, according to Fairclough \& Wodak (1997), implies a dialectical relationship between a particular discursive event (such as blame) and the situation(s), institution(s) and social structure(s), which frame it. A given discursive event such as blame is socially constitutive as well as socially conditioned - it constitutes situations, objects of knowledge, and the social identities of and relationships between people and groups of people. van Dijk (1997) considers discourse as a form of spoken language, (https://hdl.handle.net). Building on this theoretical plank, van Dijk (1998) goes further to underscore the particular directions of language in which discourse sheds light on language use and social interaction in communication, for instance, interviews, conversations, meetings, letters, diaries, propaganda, discussions, laws, contracts, political discourses, songs, poetry, and news, (http://consortiacademia.org/). van Dijk (1998) considers language as influential factor for society through which people's identities, ideologies, and mutual knowledge are constructed. In spite of their different disciplinary backgrounds and a great diversity of methods and objects of investigation, such related disciplines as pragmatics, sociolinguistics, ethnography of speaking, conversation analysis and discourse studies all deal with discourse and have at least seven dimensions in common as identified by van Dijk (2007) and Wodak, 2008a (https://pt.scribd.com).

From the foregoing, it seems tenable to contend that the concept of blame as a social practice fits into the theoretical frame of a typical discourse amenable to analysis based on relevant discursive strategies. The 2015 general elections featured two dominant political parties - the ruling Peoples' Democratic Party (PDP) and the opposition All Progressive Congress (APC). The ruling party was defeated in the March 28 presidential and National Assembly elections and it lost massively in the April 11 governorship and state Houses of Assembly elections. The massive electoral defeat it suffered set off a hurricane of intra-party discord, acrimony, recrimination, accusations and counter-accusations. The visceral 
bout of confidence crisis and blame-game, which Olisa Metuh described as a product of Election Defeat Trauma (EDT), pitted the Presidency, PDP governors, the PDP Presidential Campaign Organisation as well as some leaders of the party against its National Working Committee. When a political system experiences a setback in the form of electoral defeat, it raises various issues that border on blameworthiness, blame judgment and management. Such norm-violating event, which engenders linguistic and contextual framing has been proved to affect people's reasoning in a variety of domains (e.g., Levin, 1987; Loftus \& Palmer, 1974; Tversky \& Kahneman, 1981) (http://www.psych.stanford.edu).

This paper examines how PDP members locked up in a kind of politically-motivated 'mutually-assured destruction' (MAD), worked hard to undermine an objective appraisal of the 2015 general elections through self-absolving speech acts intended to avoid responsibility and reframe the 'problem' of electoral defeat. This is achieved by engaging in political debates and persuasive discourses intended as a convenient leverage for mitigating blame of moral responsibility, in which blaming and denying, by serving to promote one group and ascribe blame for electoral defeat to the 'other,' are carefully and strategically planned to achieve the twin objectives of positive self-presentation and negative other-presentation.

\section{Conceptualising Blame as a SPeech Act}

Blame presupposes the act of expressing disapproval or reproach about the action(s) or statement(s) of someone or group. Searle and Vanderveken, (1985: 191) cited in Al-Ameedi, et. al. (2016:1), define the speech act of blame as "the act of disapproving or condemning something bad." Blame, notes Williams (2006:12) in Al-Ameedi, et. al. (p.2), "is the act of expressing disapproval, negative feeling, censure, or annoyance towards a past or ongoing action whose consequences are perceived to the addressee's responsibility," (https://jourhum.com). In pragmatics and philosophy, blame as a speech act is conceptualized variously as behabitive, assertive, expressive or verdictive. As Al-Ameedi, et. al. (p.3) note, Austin (1956:35), Austin (1962: 83), and Nozick (2000:108-9) see blame as a kind of social behaviour, hence its classification as behabitive, while Searle and Vanderveken (1985: 182-3), Vanderveken (1990:169) and Downs (1998: 378-9) classify blame as assertives, with assertive illocutionary forces, which "have the preparatory condition that the addresser has a reason, ground or evidence that supports the truth of the propositional content," (https://jourhum.com). For Proost (2007) in Al-Ameedi et. al., blame is an expressive act meant to express "a negative evaluation by the addresser of some past action performed by the addressee," (https://jourhum.com). From the theoretical perspective of Kreidler (1998) also in Al-Ameedi, et. al., blame comes under the category of verdictive, that is, "speech acts in which the speaker makes an assessment or judgment about the acts of another, usually the addressee". The foregoing conceptualization of blame provides a basis for examining it as a form of expressive and verdictive speech act, which manifests in the electoral defeat discourse in Nigeria, the analysis of which follows in the subsequent sections.

\section{FRAMEWORK}

The framework adopts an eclectic approach that combines aspects of speech act theory, conversational analysis, van Dijk's perspective of critical discourse analysis, and argumentation theory. To analyze the speech act of blame in this study, we follow certain felicity conditions as outlined by Al-Ameedi, et. al. (2016: 18-9), which are necessary and sufficient for the act of blame to be successfully performed in the utterances of the parties involved in the electoral defeat discourse. The felicity conditions suggested here are as follows:

i - Comprehensive conditions (CCs): The addresser should specify a particular addressee(s).

ii - Propositional content conditions (PCCs): (a) A bad proposition P has been achieved; (b) Some individual is responsible for the existence of the state of affairs.

iii - Preparatory conditions (PCs): (a) The addresser has as evidence or a reason to blame (P/ addressee/addresser himself/ or another agent); (b) A harmful effect has been received /or ongoing received by the addresser, and/ or the addressee and/ or another agent.

iv - Sincerity conditions (SCs): The addresser is discontent and believes that the state of affairs is bad and blameworthy.

$\mathrm{v}$ - Essential conditions (ECs): The utterance counts as dissatisfaction or expression of blame to the effect that $\mathrm{P}$ represents the actual state of affairs, (https://jourhum.com).

The value of Conversation Analysis (CA) to sociolinguistics as a discipline that contextualises language derives from the structuring of conversation as contiguous and alternating turns of talk referred to as 'adjacency pairs'. In their discussion of dialogic approaches to discourse analysis, Hill \& Irvine (1993:1) note that "many aspects of linguistic form may usefully be seen as having interactional processes profoundly embedded in them" Here, adjacency pairs are claimed as one such, (http://www.pragmaticshumour.net/). An adjacency pair refers to a unit of conversation, which entails "an exchange of one turn each by two speakers," which are related in functional terms such that the first turn elicits a functional equivalent turn from the second speaker. In other words, the first part of an adjacency pair produces the expectation of a relevant and acceptable rejoinder in the second part, (http://www.idcw.com/beian.asp). (http://dsbigham.net/ling101sdsu/2014/10/page/2/ https://glossary.sil.org/term/adjacency-pair). Schegloff and Sacks (1973:295-6) state that an adjacency pair has these features: two utterance length; adjacent positioning of the 
component utterances; different speakers producing each utterance; relative ordering of parts i.e., first pair parts precede second pair parts; discriminative relations i.e., the pair type of which a first pair part is a member is relevant to the selection among second pair parts, (http://www.pragmaticshumour.net/). Such pairs can be question-answer, greetinggreeting, blame-denial/admission, request-grant/refusal, invitation-acceptance/declination, compliments/response. In the same sense that question-answer exemplifies an adjacency pair, so shall we treat the blame-denial 'tied pair', which tends to characterize the electoral defeat discourse as evident in the speech acts of blame outlined in the Appendices.

van Dijk's (2002) perspective of critical discourse analysis (CDA) takes ideology as the attitude a group of people hold towards certain issues and describes the political discourse as the most ideological. Later, van Dijk (2004) reformulated his approach, which consists of two main discursive strategies of 'positive self-representation' (semantic macro-strategy of in-group favouritism) and 'negative other-representation,' that is, semantic macro-strategy of derogation of out-group, (http://ejournal.stkip-pgri-sumbar.ac.id/). In the framework, van Dijk elaborates on 27 ideological strategies among which the fundamental dichotomy of 'self positive-representation' and 'other negativerepresentation' stands out, (http://www.uab.ro/). In this paper, we examine a number of argumentative moves made by the key interactants involved in the blame game, ranging from attacking the opponent personally (argumentum ad hominem) or threatening the opponent and his/her freedom of expression (argumentum ad baculum) (https://www.lancaster.ac.uk/linguistics/). Another set of argumentative moves include authority (argumentation), evidentiality (meaning argumentation), generalization (meaning argumentation), and number game (rhetoric argumentation).

\section{DATA ANALYSIS}

Here, we analyse the speech acts of blame as produced by the parties to the conflict. To this effect, we shall establish the felicity conditions of the speech acts of blame, present the adjacency pairs of blame/denial, discursive strategies of positive-self/negative-other presentations and argumentative moves.

\section{A. Felicity Conditions of Blame Speech Acts}

In line with the felicity conditions aforementioned (section 3), we shall analyse a sample of the speech acts of blame, which represents an aggregate of the entire speech acts that make up the corpus elicited from the online editions of Nigerian print media.

SA 1: 'Hate campaigns of First Lady, Fayose caused Jonathan's defeat' - PDP National Working Committee.

Here, Olisa Metuh is addressing the PDP Presidential Campaign Organisation (PDPPCO) led by Amadu Alli. Implicitly, there is a very strong blame for PCO members for their bad conduct. The major reason is that the PDO allowed Jonathan's campaign spokesman Femi Fani-Kayode, Ekiti State Governor Ayo Fayose, presidential aide Dr. Doyin Okupe and First Lady Patience Jonathan to lead the hate campaign, which caused PDP's electoral defeat. "The decision of the PCO to adopt and execute a hate campaign strategy against the then presidential candidate of the APC, Gen. Muhammadu Buari led to the failure of PDP," Mr. Metuh said (http://nigerianseers.blogspot.com). From the foregoing, the FCs of this speech act are established as follows:

1 - The CCs: Metuh is addressing PDPPCO; 2 - The PCCs: noting their blameworthy action of hate campaign; 3 The PCs: the hate campaign is the root-cause of PDP's electoral loss; 4 - The SCs -Metuh expresses discontent at the norm-violating event, which he considers blameworthy; 5 - ECs - The statement counts as a dissatisfaction and implies a severe blame of PCO's action, (https://www.allafrica.com).

SA 2: "Moles in the Party working for APC led to PDP's defeat," - Femi Fani-Kayode.

Here, Fani-Kayode is addressing Metuh's NWC. Implicit in this address is outright denial of the blame and avoidance of responsibility for the electoral defeat. His allegation of sabotage is based on authority information on the underhand dealings of the moles. From this, we distill the following FCs of the speech act:

1 - The CCs: Fani-Kayode replies Metuh; 2 - The PCCs: an action, which the addresser considers blameworthy is denied; 3 - PCs: promise to provide evidence that supports addresser's claims; 4 - SCs - addresser disproves of the blameworthy action; 5 - ECs - statement of disapproval implicates blame of NWC's action.

SA 3: "The road to electoral losses of the PDP started from its December 2014 primaries, when the governors deliberately shut out 'unwanted candidates' and imposed their choices on the party."- Victor Ndoma-Egba, (http://www.abusidiqu.com/). In this speech act, the speaker is addressing the PDP Governors. The speech implicates blame of the action, i. e. imposition of candidates, which caused discontent among members, the speaker inclusive. The blameworthy action led to mass exodus from PDP without corresponding influx. The net-effect is electoral losses. The FCs of the SA are distilled thus:

1- The CCs: Speaker addresses the Governors; 2 - The PCCs: The candidate imposition as bad proposition (P) is achieved; the agents of the P is identified; 3- PCs: A harmful effect of the P is received in form of mass defections; 4 SCs - The addresser disapproves of the P as blameworthy; 5 - Ecs: The addresser's discontentment as implicit in his statement implies blame of the P.

SA 4: "Those who were 'praise-singing and insincerely advising' the President during the campaign period were responsible for PDP's defeat at the presidential poll.” - Adamu Muazu, (http://www.aice11.blogspot.com)

In this case, the speaker addresses certain unnamed persons. These persons' 'sins' are identified as praise-singing and 
bad advice. The effect of these sins is responsible for the electoral loss. The action of these persons is blameworthy. The SA has the following FCs:

1 - CCs: Speaker addresses a group of people; 2 - PCCs: Praise-singing and bad advice as constituting a bad proposition $(\mathrm{P})$ is achieved; 3 - PCs: The system feels the adverse effect of the P; 4 - SCs: Speaker is unhappy with the state of affair; 5 - ECs: The utterance implies expression of blame to the effect that P represents the actual state of affairs.

SA 5: "PDP lost because of Muazu's underhand dealings with the APC." - Ayodele Fayose

Here, the speaker addresses Muazu; accuses him of sabotage; this action caused PDP's defeat; this action is blameworthy; Muazu should mitigate the effect of the action by resigning. The FC of the SA is outlined thus:

1 - CCs: Speaker addresses Mauzu; 2 - PCCs: Sabotage is identified as constituting a bad Proposition (P); 3 - PCs: Speaker has evidence to associate $\mathrm{P}$ with the addressee; 4 - SCs: Speaker relies on blameworthiness of P in justifying his discontentment with the addressee; 5 - ECs: The statement counts as a discontent disposition, which implies a severe blame of addressee's action.

SA 6: "Jonathan was a victim and target of international cum domestic esoteric codes and conspiracies..." - Osom Makbere

In this SA, the speaker addresses an indeterminate audience; identifies factors (internal/external) that caused PDP's defeat. The FC's outline is as follows:

1 - CCs: Speaker addresses nobody in particular; 2 - PCCs: identifies local and international conspiracies as crux of the bad P; 3 - PCs: considers the causative agents of PDP's electoral loss as blameworthy; 4 - SCs: disapproves of the P; 5 - ECs: statement of disapproval implicates blame of the P.

SA 7: "The PDP chairman did not have the party's interest at heart from the time the party started campaigns...Mu'azu is the number one mole planted in the PDP to destroy it... he was the number one culprit for the dismal outing of the PDP... Ahmed Gulak

In this SA, the speaker pointedly identifies PDP chairman as the architect of the Party's electoral woes; hinges his claims on (real/imagined) treacherous disposition of Muazu; such action is bad, blameworthy, and requires immediate mitigation by Muazu's resignation as Party chairman. We establish the FCs of the SA as follows:

1 - CCs: Speaker specifies a particular addressee, Mr. Muazu; 2 - PCCs: He achieves a bad proposition P by identifying Muazu as a 'mole' in PDP; 3 - PCs: Speaker identifies the adverse effect of the bad P on the Party and provides evidence to associate $\mathrm{P}$ with the addressee; 4 - SCs: Speaker expresses disapproval of P implying that the state of affairs engendered by $\mathrm{P}$ is bad and blameworthy; 5 - ECs: Speaker's statement mirrors his discontentment and implicates expression of blame to the effect that $\mathrm{P}$ typifies the real state of affairs.

\section{B. Blame-denial Adjacency Pair}

In a typical adjacency pair, the conversation is structured in a way that the first part of the pair imposes a requirement on the interlocutor to supply the second part of the pair. This resonated sonorously in the speech acts of blame being investigated, which created a kind of conversational dynamic that sought to cast the problem of PDP's electoral defeat in the mould of blame-denial dialogic exchanges. In blazing the trail of blame game, Olisa Metuh holding brief for PDP's National Working Committee, blamed PDP's loss at the poll on the hate campaign of the Presidential Campaign Organisation against Buhari of the APC. Metuh's efforts were complemented by Mohammed Tsav. The pragmatic function or purposive intention of the speakers in the first part constrains the kind of pragmatic function of the second part, which is outright denial of the blame. This is explicit in the rebuttal provided by Fani-Kayode when he described such speech acts as "unfair and mischievous."

His denial aligns with the principles of blame management as evident in extant literature (cf. Benoit, 1995; Cupach \& Metts, 1994; Goffman, 1967; Dersley \& Wootton, 2000; Alberts, 1989). In managing blame and by extension mitigating its perlocutionary effect, the defender usually resorts to denying the 'norm-violating event' as reported by Metts (1994) and Newell \& Stutman (1988). Where either of such claims turns out to be true as Dersley \& Wootton (2000) observe, it would keep the defender blameless, although strategic event denials without good evidence rarely succeed. The offender, note Scully \& Marolla (1984), can also try to dispute the nature of the alleged norm-violating event or claim that the event itself is not norm-violating.

The flipside of the blame-denial adjacency pair originated from the harried team of Ayodele Fayose, Ebenezer Babatope, Babangida Aliyu, Ahmed Gulak, and Olabode George, who laid the blame of PDP's defeat squarely on the NWC members, a blameworthy action, which imposes a moral burden on them to resign immediately. By engaging in a communicative speech act of blame that reprimands with feeling, Fayose and company had hoped to bring the wrongdoers to appreciate the magnitude of the blameworthiness and perhaps effect a behaviour change. Initially, the speech act of communicative blame intended to bring the NWC members to feel the proper pang of remorse, failed to cut ice with the blamees. Instead, it elicited a kind of pragmatic function of the second part, which is flat denial of the blame. This is reflected in their separate responses. (See Appendices vii, viii, x, xii, xiv, xvi). However, Muazu's defiant disposition seemed to have had a fragile frame that broke down too quickly to sustain his cling to the chairmanship position, one which he relinquished while on medical tourism overseas. By throwing in the towel, Muazu had tended to justify the effect of communicative blame, which is to be intended to bring about a positive behavioural change in the wrongdoer. Nonetheless, the burden of guilt and blameworthiness was not weighty enough to sway Metuh and other 
NWC members away from their defiant path of doggedness, which explains the failure to forge a common moral ground between the wrongdoer and blamer.

\section{Discursive Strategies of Ideological Discourse Structures}

In this section, we examine the ideological strategies of positive self- and negative other-presentations and argumentative moves and explore the extent to which the electoral defeat discourse reflects them. Positive selfpresentation and negative other-presentation are two complementary strategies, which focus on participants as social groups rather than individuals (van Dijk, 1993). Some researchers (see, for example, the works of van Dijk (1987, 1993), Fowler (1991), have paid particular attention to the role of language in the construction of social consensus regarding the in-group 'us' as against the out-group 'them'. The analysis of what van Dijk (2007:78) refers to as 'ideological square,' that is, “(i) Emphasize Our good things; (ii) Emphasize Their bad things; (iii) De-emphasize Our bad things; (iv) De-emphasize Their good things" (http://eprints.undip.ac.id) is an aspect of what he sees as the need "to relate properties of discourse with these underlying, socially shared, representations, which group members use as a resource to talk about (members) of other groups" (van Dijk, 2016). Therefore, a given discourse is considered ideological when people as in-group members talk in terms of we and are disposed to evaluating their policies, actions, and statements in positive terms as well as defending their sectarian interests. In this study, we set out to demonstrate how the use of cognitive processes associated with 'we' reveals not only how the electoral defeat discourse interactants categorise $U s$ and Them, but also their judgment of $U s$ as good and Them as bad. This positive-self presentation is clearly expressed in Fani-Kayode's denial of hate campaign accusation, wherein he reframed the electoral defeat discourse:

We are serious-minded, patriotic, loyal, faithful, responsible and hard-working party leaders, who chose to answer a call to duty by our President and made massive sacrifices in terms of time, energy, commitment and risk, and stood up for our President when asked to do so...(https://www.allafrica.com). This was a great achievement for which we ought to be thanked and not one for which we should be maligned, misrepresented and insulted...(http://www.abusidiqu.com/).

The NWC led by Muazu and Metuh took turns to 'express/emphasize information that is positive about $U s$ and express/emphasize information that is negative about Them'. In his words, Muazu passed his judgment of $U s$ as good and Them as bad thus: "We went to every state in Nigeria to campaign. In the face of abuse, insult and open ridicule by our friends and brothers, we supported our leader President Jonathan faithfully... the perception of President Jonathan and our party in the north was at an all-time low because of the lies they were told by politicians..." He was equally quick to shriek the responsibility of getting President Jonathan re-elected: "Those who blame us for not delivering maximum votes to the president in the north seem to have forgotten that it's the people who vote..." (http://dailyindependentnig.com/). If I had my way, everyone in my state, Bauchi would have voted for President Jonathan but it's the people that vote not me," (https://www.graphittinews.blogspot.com). For Metuh, the tale of positive-self presentation was told with mellifluous suavity and patrician cadence:

...For the avoidance of doubt, we wish to state categorically that this national leadership has remained very transparent in all its dealing since coming into office, (http://www.abusidiqu.com/). We state clearly that we have not been given any money, rather this NWC generated billions of naira from the sales of forms from where we funded our candidates for governorship and State Assembly elections in all the states of the federation..." (https://www.agiolycia.blogspot.com).

The second pair of the ideological square, i.e., suppress/de-emphasize information that is positive about Them and suppress/de-emphasize information that is negative about Us (Russi, 2016) was volubly expressed with equal verve and intensity from both sides of the ideological divide. From the NWC perspective, Metuh and Muazu complemented one another in the use of cognitive processes associated with we against them and polarized relationship between the antagonistic ideological groups as evident in excerpts xvi (http://saharareporters.com/2015/05/05/president-jonathanresponsible-his-defeat-\%E2\%80\%93-olisa-metuh) and xix (xix https://naijasly.blogspot.com/2015/05/why-adamumuazu-is-not-to-blame-for.html). Conversely, the 'other' group of the ideological divide led by Fani-Kayode equally proved formidable in the tactical deployment of the combined strategies of positive-self and negative-other presentations as explicit in his own interpretation of the second pair of the ideological square. His words:

They are simply incapable of defending the President and his legacies after he has left office, and neither are the majority of them even ready to do so, (http://www.abusidiqu.com/). The truth is that their allegation is not only baseless but also unadulterated rubbish, and those who made them are nothing but ingrates, cowards and traitors who know nothing about politics, political campaigns, intellectual discourse or political engagement, (http://dailyindependentnig.com/). They are fueled by hate and envy, and worst of all, right from the start, they had no interest in fighting for our leader and candidate, President Jonathan, or in ensuring that he won the election..." (https://www.allafrica.com).

The foregoing contextual strategy of positive-self and negative-other presentations have tended to provide ample justifications for van Dijk's (2000) socio-cognitive model of Critical Discourse Analysis (CDA). van Dijk (1998:23) argues that his model is able to deal with the ideology-laden issues since a socio-cognitive approach "is able to explain how ideologies monitor practices of social actors in the society." Van Dijk's (2000) model also considers discourses to clarify the roles of ideologies through which texts and talks are constructed, of processes participants go through in understanding ideological discourse and of the ways discourse may be manipulated to construct ideologies 
(http://consortiacademia.org/).

\section{Argumentative Moves}

1. Argumentum ad hominem

This type of argumentative move constitutes an attack on an argument made by attacking the person that made the argument, instead of attacking the argument directly. A glimpse of this kind of argumentative move is gleaned from Fani-Kayode's virulent barbs as quoted above. Toeing the same line of argumentum ad hominem, Governor Fayose rained vituperative attacks on Adamu Muazu: "I am even more particular about the national chairman because he sold the party to the opposition" (http://www.abusidiqu.com/).

2. Argumentum ad baculum

The strength of this form of argumentative move flows from the appeal it makes to the timidity or fear of man and this appeal turns into fallacy if it fails to maintain logical relationship between it and the claim being made. Put differently, the emotion driven more by a threat than a cogent reason suffices as a trigger of alignment with the apparent conclusion of the argument. This move, by implication presupposes a threat, which is informed by the idea that 'might makes right,' (http://paxexsistovos.blogspot.com/2012/) Again, Fayose's attack on Muazu intended as a brazen tool of intimidation is quite illustrative: I have cogent evidence of his unholy alliance with the opposition before the elections and if they go any further, I will expose all his underhand deals" (http://www.abusidiqu.com/). Here, the ad baculum constitutes a thinly-veiled threat intended to vaporize Muazu's integrity as Party Chairman and force him to resign. The gamble paid off as the embattled Chairman eventually relinquished his chairmanship position after initial hesitation.

3. Authority argumentation

This form of argumentative move predisposes the interactants to take recourse to the fallacy of mentioning authorities to support their case, usually organizations or people who are above the fray of party politics, or who are generally recognized experts or moral leaders. International organizations (such as the United Nations, or Amnesty), scholars, the media, the church or the courts are often enlisted to play such role of argumentative move (http://www.discourse-in-society.org/). In the case of the present study, those who oppose the NWC members (Governor Fayose, Ebenezar Babatope, and Olabode George) cite the case of Party leaders' resignation in Britain as an exemplary step that should be taken by the NWC members. (See Appendices ii, iii, xiii). All of these were in reference to Ed Miliband's resignation statement in Appendix xxii. In his own authority argumentative move, Olisa Metuh cited historical antecedents to substantiate his hate campaign theory, (See Appendices xiii). In all of these, interactants of different ideologies typically cite different authorities that tend to support their respective ideological leanings.

4. Evidentiality (meaning argumentation)

This is one of the ideological discourse structures of van Dijk's (2004) framework, which suggests that claims or points of view in argument are more plausible when speakers present some evidence or proof for their knowledge or opinions. This may happen by references to authority figures or institutions (as seen in the preceding sub-section), or by various forms of evidentiality (http://www.discourse-in-society.org/). To this effect, Osom Makbere provides evidence of 'international cum domestic esoteric codes and conspiracies' to prove Jonathan's victimhood that paved the inglorious way to the electoral defeat. Also, Metuh, Muazu, and Tsav provided evidence of hate campaign by FaniKayode, Mrs. Jonathan, and Gov. Fayose and raising of derogatory allegations against the APC presidential candidate, Gen. Buhari to explain PDP's defeat. For instance, Fani-Kayode's allegation of Buhari's connection with terrorist organizations, Fayose's 'death-wish' advert, and Mrs. Jonathan's claim that Buhari was 'brain-dead' and her 'stone them' inciting statements were cited as evidence of hate campaign that cost PDP victory.

5. Generalization (meaning argumentation)

In generalization as a form of meaning argumentation, interlocutors refrain from providing concrete accounts of events. Instead, they make generalizations about the electoral defeat discourse to formulate prejudices against members of the opposed ideological camp. This type of argumentative move is evident in the statements of Bode George and Ndoma-Egba. (See Appendices v, vi).

6. Number game (rhetoric argumentation)

According to van Dijk (2004), much argument is oriented to enhancing credibility by moves that emphasize objectivity (http://www.slidelegend.com). Numbers and statistics are the primary means to persuasively display objectivity. In the case of this study, some interactants relied partly on number game as a form of rhetoric argumentation to drive home their points. Prominent among them was Metuh and Fayose. For Metuh, fine numerical details were needed to lend credibility and objectivity to his own account of the electoral defeat discourse. (See Appendices viii). In apparent response to Metuh's number game, Fayose offered a rebuttal (Appendix xv). In all of this, we notice how these ideological discourse structures operate and offer insights into how ideologies monitor practices of social actors in the society.

\section{CONCLUSIONS}

In this paper, we examined the discursive strategies of electoral defeat discourse and how the linguistic mechanism of blame and avoidance of responsibility thrives as a dominant recurrent theme in conflict talk and public communication discourses in Nigeria. By examining the conversational 'discursive practices' adopted by Nigerian politicians 'in the 
circumstances of blame risk to achieve' the twin goals 'of positive self-presentation' and consolidation of political capital, the linguistic account of blame is intended not only as a contribution to discourse studies but also seeks to open fresh vistas of critical research into language use in politics (Hansson 2015: 301). To this effect, a number of speech acts of blame elicited from the public statements of the political actors as reported in the online editions of Nigerian newspapers were analysed by establishing the felicity conditions of the speech acts, which are necessary and sufficient for the act of blame to be successfully performed in the utterances of the parties involved in the electoral defeat discourse (https://jourhum.com). Furthermore, the speech acts of blame were accounted for in terms of adjacency pairs of blame/denial, positive-self/negative-other presentations. The discursive strategies of 'positive self-representation' (semantic macro-strategy of in-group favouritism) and 'negative other-representation' (semantic macro-strategy of derogation of out-group) show that ideological discourse often features overall strategies of van Dijk's (2004) 'ideological square'(http://www.uab.ro/). Apart from the ideological square, the electoral defeat as a discourse featured other such subtle ideological discourse strategies as actor description, polarization, Us-Them categorization, selfglorification, victimisation, and a number of argumentative moves including authority, evidentiality, generalization, and number game argumentations. In summary, insights from speech act theory, discourse analysis, and conversation analysis are explored and adopted as analytical means of establishing the communicative and interactional character of speech act of blame as a discourse, which as van Dijk (1997) surmises, involves social matters through which language is utilized for communication and also expression of feelings, ideas, and beliefs (http://consortiacademia.org/).

\section{APPENDIX}

(i) "It is unfortunate that people had to be called to resign. The leaders are supposed to voluntarily resign their positions for the loss at the just concluded general elections..." - Governor Babangida Aliyu (https://dailypost.ng/2015/05/10/aliyu-asks-muazu-others-to-resign-as-lamido-names-road-after-g7-governors/)

(ii) "From the example of what has happened in Britain where leaders of the Labour Party have resigned as a result of the elections, this is a step that should naturally be taken by any party that has lost an election... - Ebenezer Babatope (https://www.africanewshub.com/news/3078835-pressure-mounts-on-muazu-others-to-resign-before-may-29)

(iii) "You saw how the Labour and Liberal leaders resigned after losing elections in the United Kingdom..." - Olabode George (https://www.latestnigeriannews.com/news/1484410/pressure-mounts-on-muazu-others-to-resign-before-may$\underline{\text { 29.html) }}$

(iv) "The PDP chairman did not have the party's interest at heart from the time the party started campaigns...If the belief of the majority of the members of the PDP is anything to go by, you could say that the party chairman was the number one culprit for the dismal outing of the PDP." - Ahmed Gulak (https://theeagleonline.com.ng/muazuresponsible-for-defeat-of-jonathan-pdp-gulak/)

(v) "The PDP lost the elections because of unresolved issues and due to the handiwork of enemies within..." - Olabode George (https://dailypost.ng/2015/05/03/pdps-enemies-made-us-lose-elections-bode-george/)

(vi) "The road to the March 28 and April 11 electoral losses of the PDP actually started from its December 2014 primaries, when the governors deliberately shut out "unwanted candidates" and imposed their choices on the party..." Victor Ndoma-Egba (https://guardian.ng/news/ndoma-egba-blames-pdp-govs-for-partys-polls-loss/)

(vii) "The hate campaign played a huge part in the PDP's woeful outing at the last general elections..." - Olisa Metuh (https://www.premiumtimesng.com/news/headlines/182424-pdp-crisis-party-blames-hate-campaign-for-jonathans.html) (viii) "We (NWC members) did not lead the party to failure. If we had handled the campaign, Mr. President would have won the election...Olisa Metuh (https://www.premiumtimesng.com/news/headlines/182424-pdp-crisis-party-blameshate-campaign-for-jonathans.html)

(ix) "I have no apology on my position on the NWC because their responsibility as a party does not take away their failure in the last general elections... Ayodele Fayose (https://www.premiumtimesng.com/politics/182482-pdp-crisisfayose-hits-back-at-exco-says-muazu-betrayed-party-2.html)

(x) "Those who were "praise-singing and insincerely advising" the President during the campaign period were responsible for PDP's defeat at the presidential poll..." - Adamu Muazu (https://www.herald.ng/muazu-deniesconspiring-with-apc-to-defeat-jonathan/)

(xi) "Jonathan's loss could be blamed on a multiplicity of interwoven causes. Jonathan was a victim and target of international cum domestic esoteric codes and conspiracies..." Osom Makbere (https://www.nairaland.com/2277881/patience-jonathans-attitude-cost-us /)

(xii) The party headquarters was sidelined during the campaigns, and that "overzealous" persons were allowed to run a hate campaign against Mr. Buhari...Olisah Metu (https://www.legit.ng/428042-2015-pdp-chief-speaks-about-reasonsfor-jonathans-loss.html)

(xiii) "It is morally wrong for the national chairman to remain in office after leading the party to its first national electoral loss..." -Fayose (https://web.thecable.ng/muazu-resign-like-uk-party-leaders)

(xiv) "Those who insinuate that I did not do my best for our great party and Mr. President during the elections are being economical with the truth..." - Adamu Muazu (https://web.thecable.ng/muazu-couldnt-force-people-vote-gej) 
(xv) "Only N30m was received for the last two elections and to the glory of the Almighty God and support of Ekiti people, we won all elections outright..."- Fayose (https://www.legit.ng/433311-fayose-pledges-allegiance-to-pdpinsists-on-muazu-dismissal.html)

(xvi) "The NWC advised such party officials against hate speeches, but that the advice and suggestions were ignored. We cannot be held responsible for the failure..." - Olisa Metuh (http://saharareporters.com/2015/05/05/presidentjonathan-responsible-his-defeat-\%E2\%80\%93-olisa-metuh)

(xvii) "The leadership of PDP was unconcerned about obvious irregularities that characterised the party's primary that led to its shameful and disgraceful defeat..." - Sara-Igbe (https://www.pmnewsnigeria.com/2015/05/08/pdp-lost-tolack-of-internal-democracy-ex-security-adviser/)

(xviii) The party was taken over by Mrs. Jonathan, Gov. Fayose, Femi Fani-Kayode among others..." - Tsav (https://dailypost.ng/2015/05/06/tsav-blames-patience-jonathan-fani-kayode-fayose-for-pdps-defeat/)

(xix) If you watch my utterances personally, you will find that there is nothing I do than to be a good salesman of what I should be, for my party and for my President. "Unfortunately, when the opposition goes haywire, some of our small boys in our own party also shout back..." - Adamu Muazu (https://naijasly.blogspot.com/2015/05/why-adamu-muazuis-not-to-blame-for.html)

(xx) "The president fought against evil conspiracies both locally and internationally in his bid to deliver good governance to the people of the country..." - Doyin Okupe (https://allafrica.com/stories/201505112560.html)

(xxi) "How could you lead a party to disastrous outing in an election and you are still in that place, take the blame for the defeat by quitting?" - Babangida Aliyu (https://allafrica.com/stories/201505180948.html)

(xxii) 'I take absolute and total responsibility for this result and our party's loss in this election. Now it's time for someone else to take forward the leadership of the party. So, I am tendering my resignation" - Ed Miliband (https://www.independent.co.uk/news/uk/politics/generalelection/ed-miliband-resigns-the-labour-leaders-resignationspeech-full-text-10236019.html)

\section{REFERENCES}

[1] Abimboye, Michael (2015, September 28). PDP Crisis: Mu'azu, Fayose clash on Twitter. Retrieved from: www.premiumtimesng.com.

[2] Adams, Didi. (2015, May 20). Jonathan would have suffered worse defeat if we didn't help - Fani-Kayode. Retrieved from: www.thisdaylive.com.

[3] Adoyo, Sarah. (2015, May 7). PDP chief speaks about reasons for Jonathan's loss. Premium Times Retrieved from: https://www.legit.ng/428042-2015-pdp-chief-speaks-about-reasons-for-jonathans-loss.html.

[4] Al-Ameedi, R. T. K., Al-Najjar, A. M. A., Al-Khafaji, \& S. S. M. A. (2016). Blame in English And Arabic religious texts: A pragmatic study. Retrieved from: https://www.researchgate.net/publication/312043870_Blame_in_English_and_Arabic_Religious_Texts_A_pragmatic_Study/li nk/586c8e9408ae6eb871bb75ce/download.

[5] Alberts, J. K. (1989). A descriptive taxonomy of couples' complaint interactions. Southern Communication Journal, 54:2, 125143, DOI: $10.1080 / 10417948909372751$.

[6] Austin, J. (1956). "A Plea for Excuses". Republished in Proceedings of Aristotelian Society http://www.ditext.com/austin/plea.html.

[7] Austin, J. L. (1962). How to do things with words. Oxford: Oxford University Press.

[8] Babalola, Popoola. (2015, April 19). Muazu responsible for defeat of Jonathan, PDP. Retrieved from: https://theeagleonline.com.ng/muazu-responsible-for-defeat-of-jonathan-pdp-gulak/.

[9] Benoit, W. L. (1995). Accounts, excuses, and apologies: A theory of image restoration strategies. Albany, NY: SUNY Press.

[10] Brown, Gillian and Yule, George. (1989): Discourse analysis. Cambridge: Cambridge University Press.

[11] Chilton, P. A. (2004). Analysing political discourse: Theory and practice London: Routledge.

[12] Chilton, P. A., \& Schäffner, C. (Eds.). (2002) Politics as text and talk: Analytic approaches to political discourse. Amsterdam: John Benjamins

[13] Crystal, David. (1987). The Cambridge encyclopedia of language. Cambridge, England: Cambridge University.

[14] Cupach, W. R., \& Metts, S. (1994). Facework. Thousand Oaks, CA: Sage.

[15] Dersley, I., \& Wootton, A. (2000). Complaint sequences within antagonistic argument. Research on language and social interaction, 33, 375-406. doi:10.1207/S15327973RLSI3304_02.

[16] Downes, William. (1998). Language and society. Cambridge: Cambridge University Press.

[17] Fairclough. (2001). Language and power. Longman. London.

[18] Fairclough, N. (1992). Discourse and social change. Cambridge: Polity Press

[19] Fairclough, N. and Wodak, R. (1997): Discourse studies: A multidisciplinary introduction. In T. A. van Dijk (Ed.). Discourse as social interaction. London: Sage Publications.

[20] Fausey, Caitlin M. \& Boroditsky, Lera. (2010). Subtle linguistic cues influence perceived blame and financial liability. Psychonomic Bulletin \& Review 17 (5), 644-650 doi:10.3758/PBR.17.5.644.

[21] Fowler, R. (1991). Language in the news: Discourse and ideology in the press. London: Routledge.

[22] Gee, J. P. (1999). An introduction to discourse analysis: Theory and method. NY: Routledge

[23] Gee, J. P. (2004). Discourse analysis: What makes it critical? In R. Rogers (Ed.), Critical discourse analysis in education (pp. 19-50). New Jersey/London: Erlbaum Associates Publishers.

[24] George, Taiwo (2015, May 5). Mu'azu: I couldn't force my people to vote GEJ. Retrieved from: https://web.thecable.ng/muazu-couldnt-force-people-vote-gej. 
[25] Godwin, C. Ameh (2015, May 3). PDP's enemies made us lose elections - Bode George Retrieved from: https://dailypost.ng/2015/05/03/pdps-enemies-made-us-lose-elections-bode-george/.

[26] Goffman, E. (1967). Interaction ritual: Essays on face-to-face behaviour. Garden City, NY: Doubleday

[27] Hansson, Sten (2015). Discursive strategies of blame avoidance in government: A framework for analysis. Discourse and Society. 26 (3) 297-322.

[28] Heritage J. (2008). Conversation analysis as social theory. In B. Turner (Ed.), The new Blackwell companion to social theory. Oxford, UK: Blackwell.

[29] Hill, J. H. and J. T. Irvine. (1993). Responsibility and evidence in oral discourse. Cambridge: Cambridge University Press

[30] https://www.latestnigeriannews.com/news/1484410/pressure-mounts-on-muazu-others-to-resign-before-may-29.html

[31] https://www.premiumtimesng.com/politics/182482-pdp-crisis-fayose-hits-back-at-exco-says-muazu-betrayed-party-2.html

[32] http://dsbigham.net/ling101sdsu/2014/10/page/2/

[33] https://glossary.sil.org/term/adjacency-pair

[34] http://paxexsistovos.blogspot.com/2012/

[35] http://philosophy.lander.edu/logic/force.html

[36] https://www.hse.ru/en/

[37] https://pt.scribd.com.

[38] https://hdl.handle.net

[39] http://www.psych.stanford.edu

[40] https://jourhum.com

[41] http://www.pragmaticshumour.net/

[42] http://www.idcw.com/beian.asp

[43] http://ejournal.stkip-pgri-sumbar.ac.id/

[44] http://www.uab.ro/

[45] https://www.lancaster.ac.uk/linguistics/

[46] http://nigerianseers.blogspot.com

[47] http://www.aice11.blogspot.com

[48] http://eprints.undip.ac.id

[49] https://www.allafrica.com

[50] http://www.abusidiqu.com/

[51] http://dailyindependentnig.com/

[52] https://www.graphittinews.blogspot.com

[53] https://www.agiolycia.blogspot.com

[54] https://www.paxexsistovos.blogspot.com

[55] http://www.discourse-in-society.org/

[56] http://www.slidelegend.com

[57] http://consortiacademia.org/

[58] Jide, O. (2015, May 6). Mu'azu denies conspiring with APC to defeat Jonathan. Nigerian Herald Retrieved from: https://www.herald.ng/muazu-denies-conspiring-with-apc-to-defeat-jonathan/.

[59] Jimoh, A. (2015, 24 May). FANI-KAYODE: We Defended Jonathan With All Sincerity. https://guardian.ng/features/fanikayode-we-defended-jonathan-with-all-sincerity/ Retrieved: 28 December, 2015.

[60] Jimoh, M. Azimazi \& Onochie, C. Bridget (2015, May 3). Ndoma-Egba blames PDP govs for party's polls loss. Nigerian Guardian Retrieved from: https://guardian.ng/news/ndoma-egba-blames-pdp-govs-for-partys-polls-loss/.

[61] Kreidler, W. C. (1998). Introducing English semantics. London and New York: Routledge.

[62] Levin, I. P. (1987). Associative effects of information framing. Bulletin of the Psychonomic Society, 25, 85-86.

[63] Levinson, Stephen C. (1983). Pragmatics. Cambridge, England: Cambridge University Press.

[64] Loftus, E. F., \& Palmer, J. C. (1974). Reconstruction of automobile destruction: An example of the interaction between language and memory. Journal of Verbal Learning \& Verbal Behavior, 13, 585-589.

[65] Lola Xavier (2015, April 26). Patience Jonathan's attitude cost us defeat - PDP Chief. Retrieved from: https://www.nairaland.com/2277881/patience-jonathans-attitude-cost-us /.

[66] Malle, Bertram, F., Gugliemo, Steve, Monroe, Andrew E. (2014). A theory of blame. Psychological Inquiry, 25: 147-186, DOI: 10.1080/1047840X.2014.877340.

[67] Malle, Bertram F. and Ruth E. Bennett. (1998). People's praise and blame for intention and actions: implication of the folk concept of intentionality. http://www.ibiblio.org/rcip/selfblameresearch.html\#tob.

[68] Metts, S. (1994). Relational transgressions. In W. R. Cupach \& B. H. Spitzberg (Eds.), The dark side of interpersonal communication (217-239). Hillsdale, NJ: Erlbaum.

[69] Mosadomi, Wale (2015, May 16). Nigeria: Babangida berates Mu'azu for holding on as PDP chair. Retrieved from: https://allafrica.com/stories/201505180948.html.

[70] Newell, S. E. \& Stutman, R. K. (1988). The social confrontation episode. Communication Monographs, 55:3, 266-285, DOI: $10.1080 / 03637758809376172$.

[71] Nigercenter.com (2015, May 10). Pressure mounts on Muazu, others to resign before May 29. Retrieved from: https://www.africanewshub.com/news/3078835-pressure-mounts-on-muazu-others-to-resign-before-may-29.

[72] Obiajuru, Nonso. (2015, May 5). Fayose pledges allegiance to PDP, insists on Mu'azu dismissal. Retrieved from: https://www.legit.ng/433311-fayose-pledges-allegiance-to-pdp-insists-on-muazu-dismissal.html.

[73] Odunsi, Wale. (2015, May 10). Aliyu asks Mu'azu, others to resign as Lamido names road after 'G7 Governors.' Retrieved from: https://dailypost.ng/2015/05/10/aliyu-asks-muazu-others-to-resign-as-lamido-names-road-after-g7-governors/.

[74] Oishi, Etsuko. (2006). Austin's speech act theory and the speech situation. http://www.univ.trieste.it/ eserfilo/art 106/oishi106.pdf. 
[75] Okocha, Chuks. (2015, May 5). PDP blames Jonathan's defeat on hate campaign. www.thisdaylive.com.

[76] Okocha, Chuks (2015, May 16). Nigeria: Presidency - Jonathan lost to evil conspiracies. Retrieved from: https://allafrica.com/stories/201505112560.html.

[77] Newell, S. E., \& Stutman, R. K. (1988). The social confrontation episode. Communication Monographs, 55, $266-285$. doi:10.1080/03637758809376172.

[78] Partridge, John Geoffrey. (1982). Semantic, pragmatic and syntactic correlates: An analysis of performative verbs based on English. Alle Rechte Vorbehalten: Gunter Narr Verlag Tübingen.

[79] Pickering, M. J., \& Majid, A. (2007). What are implicit causality and consequentiality? Language \& Cognitive Processes, 22, 780-788.

[80] PM News. (2015, May 8). PDP lost to lack of internal democracy - Ex-Security Adviser. Retrieved from: https://www.pmnewsnigeria.com/2015/05/08/pdp-lost-to-lack-of-internal-democracy-ex-security-adviser/.

[81] Premium Times. (2015, May 9). Fayose to PDP chair, Mu'azu: Emulate UK's Labour Party chair and resign. www.premuimtimesng.com.

[82] Proost, Kristel. (2007). Conceptual structure in lexical items. Amsterdam: John Benjamins Publishing Company.

[83] Ptimes. (2015, May 4). PDP crisis: Party blames "hate campaign" for Jonathan's defeat; opens up on campaign. Nairaland Retrieved from: https://www.nairaland.com/2293784/pdp-crisis-party-blames-hate.

[84] Russi, Cinzia. (2016). 'Current trends in historical sociolinguistics.' De Gruyter Open Poland DOI: https://doi.org/10.1515/9783110488401. Retrieved December, 2018.

[85] SaharaReporters. (2015, May 5). President Jonathan responsible for his defeat - Olisa Metuh. Retrieved from: http://saharareporters.com/2015/05/05/president-jonathan-responsible-his-defeat-\%E2\%80\%93-olisa-metuh Retrieved: 11 June 2015.

[86] Saharareporters. (2015, May 20). Fani-Kayode slams Metuh, claims APC ran malicious campaign. http://saharareporters.com/2015/05/20/fani-kayode-slams-metuh-claims-apc-ran-malicious-campaign Retrieved: 23 July 2015.

[87] Schegloff, E.A. (1968) Sequencing in conversational openings. American Anthropologist, 70: 1075-95.

[88] Schegloff E. A. (1992). Repair after next turn: The last structurally provided defence of intersubjectivity in conversation. American Journal of Sociology 95(5): 1295-1345.

[89] Schegloff, E. and Sacks, H. (1973). Opening up closings. Semiotica, 8: 287-327.

[90] Scully, D., \& Marolla, J. (1984). Convicted rapists' vocabulary of motive: Excuses and justifications. Social problems, 31, 530- 544. doi:10.1525/sp.1984.31.5.03a00050.

[91] Searle, John R. and Daniel Vanderveken. (1985). Foundation of illocutionary logic. Cambridge: Cambridge University Press.

[92] SlyNaija (2015, May 10). Why Adamu Mu'azu is not to blame for PDP's defeat. Retrieved from: https://naijasly.blogspot.com/2015/05/why-adamu-muazu-is-not-to-blame-for.html.

[93] Stone Jon. (2015, May 8). Ed Miliband resigns: The Labour leader's resignation speech - full text. Retrieved from: https://www.independent.co.uk/news/uk/politics/generalelection/ed-miliband-resigns-the-labour-leaders-resignation-speechfull-text-10236019.html.

[94] TheCable. (2015, May 8). Mu'azu 'should resign like UK party leaders'. TheCable Retrieved from: https://web.thecable.ng/muazu-resign-like-uk-party-leaders.

[95] Tukur, Sani. (2015, May 4). PDP Crisis: Party blames "hate campaign" for Jonathan's defeat; opens up on campaign funding. Premium Times Retrieved from: https://www.premiumtimesng.com/news/headlines/182424-pdp-crisis-party-blames-hatecampaign-for-jonathans.html.

[96] Tukur, Sani. (2015, May 4). PDP Crisis: Party blames "hate campaign" for Jonathan's defeat; opens up on campaign funding. Premium Times Retrieved from: https://www.premiumtimesng.com/news/headlines/182424-pdp-crisis-party-blames-hatecampaign-for-jonathans.html.

[97] Tukur, Sani. (2015, May 5). PDP Crisis: Fayose hits back at exco, says Mu'azu betrayed party. Premium Times Retrieved from: https://www.premiumtimesng.com/news/headlines/182424-pdp-crisis-party-blames-hate-campaign-for-jonathans.html.

[98] Tversky, A., \& Kahneman, D. (1981). The framing of decisions and the psychology of choice. Science, 211, 453-458.

[99] Ugwuanyi, Sylvester. (2015, May 6). Tsav blames Patience Jonathan, Fani-Kayode, Fayose for PDP's defeat. Retrieved from: https://dailypost.ng/2015/05/06/tsav-blames-patience-jonathan-fani-kayode-fayose-for-pdps-defeat/.

[100] Ukaibe, Chibuzo .(2015, May 20). Hate campaigns: Fani-Kayode blasts PDP NWC. www.leadership.ng.com.

[101] Umoru, H. (2015, August 2). I am ready for probe by DSS, says Metuh. https://www.vanguardngr.com/2015/08/iam-ready-forprobe-by-dss-says-metuh/ Retrieved: 29 November, 2015.

[102] Vanderveken, Daniel. (1990). Meaning and speech acts: Principles of language use. Vol. 1 Cambridge: Cambridge University Press.

[103] van Dijk, T. A. (1987). Episodic models in discourse processing. R. Horowitz \& S.J. Samuels, (Eds.) Comprehending oral and written language (pp.161-196) New York: Academic Press

[104] van Dijk, T. A. (1993). The principles of critical discourse analysis. Discourse \& Society, 4(2), 1993, 249-283.

[105] van Dijk, T. A. (1997). The study of discourse. In T. A. Van Dijk (Ed.), Discourse as structure and process Vol. 1, (1-35). London: Sage. http://dx.doi.org/10.4135/9781446221884.n1

[106] van Dijk, T. A. (1998). Ideology: A multidisciplinary study. London. Sage Publications.

[107] van Dijk, T. A. (2000). Ideology and discourse: A multidisciplinary introduction. London: Routledge.

[108] van Dijk, T. A. (2002). Political discourse and political cognition. In P. A. Chilton \& C. Schäffner (Eds.) Politics as text and talk. Analytical approach to political discourse. (204-236) Amsterdam: John Benjamins

[109] van Dijk, T. A. (2004). Discourse, knowledge and ideology. M. Pütz, J. Neff \& T. A. van Dijk (Eds.), Communicating ideologies: Multidisciplinary perspectives on language, discourse and social practice. (pp. 5-38).

[110] van Djik, T. A. (2006). Ideology and discourse analysis. Journal of Political Ideologies. 11(2), 115-140. http://www.discourses.org/OldArticles/Ideology\%20and\%20Discourse\%20Analysis.pdf Retrieved: December 10, 2016.

[111] van Dijk, T. A. (2007). The study of discourse: An introduction. Teun A.van Dijk (Ed.), Discourse Studies. 5 vols. Sage 
Benchmarks in Discourse Studies. (pp. xix-xlii). London: Sage.

[112] Wodak, R. (2008). 'Us' and 'Them': inclusion/exclusion - discrimination via discourse. Delanty, G., Jones, P. \& Wodak, R. (Eds.). Migration, identity, and belonging. (pp. 54-78 25). Liverpool: University of Liverpool Press.

[113] Wodak, R. (2001). What CDA is about: A summary of its history, important concepts and its developments. In R. Wodak \& M. Meyer (Eds.), Methods of critical discourse analysis (pp. 1-13). London: Sage Publications. http://dx.doi.org/10.4135/9780857028020.n1.

[114] Wodak, R., \& Meyer, M. (Eds.). (2001). Methods of critical discourse analysis. London: Sage.

[115] Williams, B. (2006). The structure of Hare's theory. A. W. Moore (Ed.) Philosophy as a humanistic discipline (pp. 76-85). Princeton: Princeton University Press.

[116] Yule, George. (1996). Pragmatics. Oxford: Oxford University Press

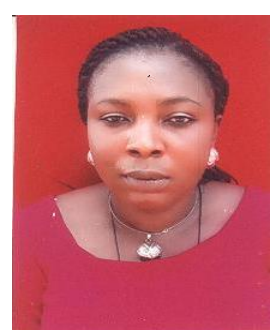

Ebere Celina Krisagbedo is a lecturer in the Use of English Unit, School of General Studies, University of Nigeria, Nsukka. She was born in Orba, Udenu Local Government Area of Enugu State, Nigeria on June 5, 1979. She obtained her Master of Arts and Bachelor of Arts in English language from the Department of English and Literary Studies, University of Nigeria, Nsukka in 2004 and 2011 respectively. Currently, she is pursuing a Doctoral Degree in English (Pragmatics) in the same Department.

She has the following work experiences:

LITERATURE-IN- ENGLISH LANGUAGE TEACHER, Urban Boys' Secondary School, Nsukka during the 2005 National Youth Service Year; SENIOR ENGLISH LANUAGE TEACHER, St. Cyprians', Special Science School, Nsukka 2006-2008; SENIOR ENGLISH LANGUAGE TEACHER, St. Francis' Secondary School, Ovoko 2010-2015. She joined the services of the University of Nigeria, Nsukka in December 2015 as an ASSISTANT LECTURER and has risen to the rank of LECTURER I. Her research interests cut across different areas of language and linguistic researches including ESL, sociolinguistics, pragmatics, discourse analysis, and applied linguistics. She has a number of book chapters and scholarly articles in national and international journals to her credit.

Mrs. Krisagbedo is a member of the following professional bodies:

Teachers Registration Council of Nigeria (TRCN);

Linguistics Association of Nigeria (LAN);

English Scholars Association of Nigerian (ESAN).

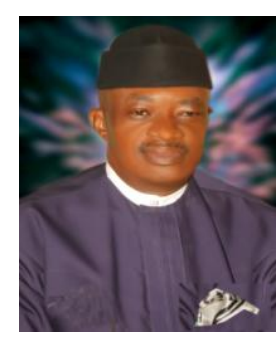

Christopher Uchenna Agbedo is a lecturer in the Department of Linguistics, Igbo \& Other Nigerian Languages, University of Nigeria, Nsukka. He was born in Olido, Elugwu-Ezikeọba, Igbo-Eze North Council Area of Enugu State Nigeria on 20 June 1965. He obtained B.A (Linguistics/Igbo), M.A (Linguistics), PhD (Linguistics) in 1986, 1991 and 1997 respectively from the Department of Linguistics and Nigerian Languages, University of Nigeria Nsukka

He has the following work experiences:

SENIOR MASTER (LITERATURE-IN-ENGLISH) - Urban Girls' Secondary School, Nsukka (1992); SENIOR NEWS EDITOR (1992-1994) - Enugu State Broadcasting Service, Enugu; ASSISTANT LECTURER (1997) - Department of Linguistics, Nnamdi Azikiwe University, Awka, He joined the services of the University of Nigeria Nsukka in 1997 as LECTURER 11 in Department of Linguistics, Igbo \& Other Nigerian Languages, University of Nigeria, Nsukka and rose to the rank of a PROFESSOR in 2011 Department of Linguistics, Igbo \& Other Nigerian Languages, University of Nigeria, Nsukka. His areas of specialisation are sociolinguistics and psycholinguistics; his research areas of interest cut across critical applied linguistics, pragmatics, discourse analysis, translation/interpretation, child communication disorders and documentary linguistics. He has authored over 100 publications, comprising 9 mainline textbooks on language and linguistics, 4 creative works (novels), 85 journal articles, 16 book chapters and 2 edited books and journals.

Prof Agbedo is a member of the following professional bodies:

Linguistic Association of Nigeria

Applied Linguistics and Literacy in Africa \& the Diaspora Research Network

American Association for Applied Linguistics

International Pragmatics Association

African Studies Global Virtual Forum, Pennsylvania State University, USA

Fellow, Netherlands Institute of Advanced Studies (NIAS-KNAW) Amsterdam

Abubakar Kadiri Ali, was born in Idah, Idah Local Government Area of Kogi State, Nigeria on $4^{\text {th }}$ July, 1972. He is a lecturer in the Department of Arts Education (English Language Unit), Kogi State University, Anyigba. He has a Bachelor of Education in English Language in 2001 from Ahmadu Bello University, Zaria, Kaduna State and obtained M.A. Linguistics (Sociolinguistics) 2011 from University of Nigeria, Nsukka, Enugu State. He is at verge of completing his Ph.D. in Linguistics (Sociolinguistics) from University of Nigeria, Nsukka, Enugu State. His major field of study is Sociolinguistics.

He worked with the Department of English, Kogi State College of Education, Ankpa. As a LECTURER 2004-2012; English Language retraining Programme for Primary School Teachers Kogi State; MDGs RESOURCE PERSON 2007 - 2012 and Department of Arts Education, Kogi State University, Anyigba. He has publications in learned journals like International Journal of Education, Learning and Development (IJELD). Vol. 3, No 7, 35-46 and International Journal of English Language and Linguistics Research IJELLR Vol.3 (1) 90 - 98.

Mr. Ali is a member of the following professional/academic associations: 
(a) Linguistic Association of Nigeria (LAN).

(b) Association for Encouraging Qualitative Education in Nigeria (ASSEQEN)

(c) European Centre for Research Training and Development UK

Ibrahim Yahaya was born in Abocho in Dekina Local Government Area of Kogi State, Nigeria on the $12^{\text {th }}$ December, 1962. He is a lecturer in the Department of English, Kogi State College of Education, Ankpa. He had a Bachelor of Education in Language Arts in 1993 from Ahmadu Bello University, Zaria, Kaduna State. He also obtained Master of Arts (M.A) in Linguistics (Sociolinguistics) in 2014 from University of Nigeria, Nsukka, Enugu State. He is currently undergoing his Ph.D. in Contact Linguistics in University of Nigeria, Nsukka. Enugu State

His work experience is domiciled with the Department of English, Kogi State College of Education, Ankpa, Kogi State from 1996 to date. He has published in both local and international Journals like British Journal of English Linguistics. Vol.7 no3, may 2019. ISSN: 2055-0820 and Journal of Education, Science, Vocational and Language Research Vol.2 No1, July, 2019

Mr. Yahaya is a member of the following academic bodies:

a. Linguistic Association of Nigeria (LAN)

b. Teachers' Registration Council of Nigeria (TRCN) 